\title{
DONGENG ABAD 21: MODERNISASI SASTRA ANAK BERBASIS PSIKOLOGI PERKEMBANGAN
}

\section{Qurrota Ayu Neina}

Jurusan Bahasa dan Sastra Indonesia, Fakultas Bahasa dan Seni, Universitas Negeri Semarang, Indonesia

\begin{abstract}
Info Artikel
Sejarah Artikel:

Diterima Juli 2018

Disetujui Agustus 2018

Dipublikasikan November 2018

Keywords:

fairy tales, developmental psychology

Abstrak

Tulisan ini memaparkan prinsip pengembangan cerita anak (dongeng) berdasarkan psikologi perkembangan anak. Penelitian ini menggunakan prosedur penelitian Research and Development (penelitian dan pengembangan). Data pada penelitian ini meliputi (1) deskripsi hasil analisis struktur cerita anak, (2) deskripsi hasil analisis keterkaitan tema dan jalan cerita dalam dongeng, dan (3) skor kecenderungan analisis kebutuhan psikologi, sosial, dan moral pada anak usia dini. Berdasarkan hasil analisis, diketahui bahwa seluruh dongeng anak nusantara tidak memiliki struktur yang lengkap. Selain itu, diketahui juga terdapat ketidaksamaan tema dengan alur, rangkaian peristiwa dalam cerita banyak berisi hal-hal yang negatif, dan hal ini bertentangan dengan nilai yang akan diajarkan pada tema. Selain itu, berdasarkan hasil sinkronisasi karakteristik data dari hasil analisis kebutuhan cerita anak pada usia dini serta pedoman mengembangankan cerita anak berbasis psikologi perkembangan, didapatkan tiga prinsip dasar pengembangan cerita anak, yaitu 1) struktur, 2) unsur intrinsik, dan 3) unsur ekstrinsik.
\end{abstract}

\begin{abstract}
This paper describes the principle of developing children's stories (fairy tales) based on the psychology of child development. This study uses Research and Development research procedures (research and development). The data in this study include (1) a description of the results of the analysis of children's story structure, (2) a description of the results of the analysis of the theme and storyline in fairy tales, and (3) the trend score for analyzing psychological, social, and moral needs in early childhood. Based on the results of the analysis, it is known that all Indonesian children's stories do not have a complete structure. In addition, it is known that there are also themes inequality with the plot, the series of events in the story contains a lot of negative things, and this is contrary to the value that will be taught on the theme. In addition, based on the results of synchronization of data characteristics from the analysis of children's story needs at an early age as well as guidelines for developing children's stories based on developmental psychology, three basic principles for developing children's stories are obtained: 1) structure, 2) intrinsic elements, and 3) extrinsic elements.
\end{abstract}

(C) 2018 Universitas Negeri Semarang

\footnotetext{
Alamat korespondensi:

Gedung B1 Lantai 1 FBS Unnes

Kampus Sekaran, Gunungpati, Semarang, 50229

E-mail: neinaqt@gmail.com
}

ISSN 2252-6315 


\section{PENDAHULUAN}

Sastra anak telah membentuk pemahaman dan wawasan setiap pembacanya. Hal ini terjadi karena ada keterlibatan antara buku atau bacaan sastra dengan pembacanya. Untuk dapat terlibat dalam cerita, terlebih dahulu harus dipahami mengenai sastra anak. Hal ini dikuatkan oleh Sarumpaet (2010) yang berpendapat bahwa sastra anak adalah karya yang khas (dunia) anak, dibaca anak, serta pada dasarnya- dibimbing orang dewasa. Dalam konteks tersebut, secara implisit dapat diartikan bahwa terdapat keterlibatan dan tanggung jawab dari orang dewasa untuk membimbing anak dalam memahami berbagai cerita yang terdapat dalam sastra anak, baik dalam memproduksi, mengkreasi, maupun mengapresiasi.

Berkaitan dengan hal tersebut, para ahli pendidikan dan psikologi perkembangan pun menyatakan bahwa perkembangan anak juga harus dipahami jika seseorang ingin mendekati dan menguasai dunia (sastra) anak. Akan tetapi, banyak sastra anak yang dijumpai saat ini belum dapat mencerminkan dunia anak dengan segala kompleksitasnya. Hal ini cenderung membuat anak-anak memiliki penafsiran yang salah terhadap isi cerita, terutama pada nilai-nilai yang terkandung di dalamnya. Ada beberapa penyebab yang perlu ditinjau ulang dalam pembuatan sastra anak ini. Faktor pertama adalah mengenai kelengkapan struktur, dan yang kedua adalah mengenai perwujudan jalan cerita dari tema yang telah ditentukan. Dua hal tersebut perlu dikaji secara mendalam, terutama dari sudut pandang psikologi perkembangan anak.

Dengan mengacu pada perkembangan anak baik secara kognitif, sosial, maupun moral, diharapkan dapat melandasi moral yang menjadi urgensi dalam pendidikan dan pengajaran dalam dunia anak. Oleh karena itu, penelitian ini secara khusus membahas mengenai wujud sastra anak, dalam konteks ini diwakili oleh dongeng, yang berkembang saat ini. Selain itu, penelitian ini juga membangun prinsip pengembangan sastra anak yang berbasis pada psikologi perkembangan. Harapannya, dengan menganalisis bentuk sastra anak yang ada saat ini dapat dikembangkan prinsip-prinsip sastra anak yang berbasis pada psikologi perkembangan yang mampu memfasilitasi anak untuk mencapai kompetensi abad 21.

Berkaitan dengan cerita anak, Titik, et al. (2003) menjelaskan bahwa cerita anak-anak adalah cerita sederhana yang kompleks. Sederhana artinya cerita tersebut tidak ruwet sehingga komunikatif, sedangkan kompleks maksudnya struktur cerita anak dibangun seperti cerita orang dewasa.

Suminto A. Sayuti seperti yang dikutip Jabrohim et.al. (2003: 105) menyebutkan bahwa struktur atau unsur-unsur yang membangun sebuah fiksi atau cerita rekaan terdiri atas tema, fakta cerita, dan sarana cerita. Fakta cerita terdiri atas tokoh, plot, dan setting. Adapun sarana cerita meliputi hal-hal yangdimanfaatkan oleh pengarang dalam memilih dan menata detil-detil cerita sehingga tercipta pola yang bermakna, seperti unsur judul, sudut pandang, gaya dan nada, dan sebagainya.

Selain itu, berkaitan dengan psikologi perkembangan, Sarumpaet (2010) menyatakan bahwa perkembangan anak harus dipahami jika seseorang ingin mendekati dan menguasai dunia (sastra) anak. Di antaranya, terdapat tiga orang ahli psikologi perkembangan yang menjadi acuan penting dalam hal ini adalah Jean Piaget, Erik H. Erikson, dan lawrence Kohlberg (Piaget 1983; Erikson 1950; dan Kohlberg 1981).

1. Teori perkembangan kognitif dari Jean Piaget menyatakan bahwa perkembangan mental dan intelektual seseorang terjadi dengan tahapan yang sedikit banyak dapat diprediksi. Terdapat empat periode utama dalam perkembangan intelektual manusia, yaitu tahap sensori motorik, tahap praoperasional, tahap operasional konkrit, dan tahap operasional formal.

2. Teori perkembangan psikososial Erikson menyebutkan bahwa selain berkembang secara kognitif, anak-anak juga berkembang secara sosial. Teori ini mengklasifikasikan proses pematangan anak melalui rangkaian konflik psikososial. Setiap konflik tersebut harus dilalui atau dimenangkan seseorang untuk dapat beranjak ke tangga perkembangan selanjutnya. Hal ini juga wajib dikuasai dan dipertimbangkan oleh orang dewasa yang berkepentingan dengan dunia anak.

3. Teori perkembangan penilaian moral dari Lawrence Kohlberg merujuk pada penilaian moral dan moral reasoning. Teori ini mempersoalkan bila dan bagaimana seseorang dapat menentukan mana yang baik dan mana yang buruk. Teori ini harus dilalui agar seseorang sampai pada kematangan moral.

Dengan mengacu perkembangan anak secara kognitif, sosial, dan moral tersebut dapat diakui bahwa anak adalah manusia utuh yang memerlukan perkembangan. Pengakuan ini juga mengikatkan kita pada permasalahan dan 
urgensi pendidikan dan pengajaran dalam dunia anak.

Penelitian terkait dengan sastra anak (cerita anak) dan psikologi perkembangan telah banyak diteliti. Pertama, Tucker (2006) dalam penelitiannya membahas usaha yang dilakukan oleh orang tua dan guru dengan menggunakan cerita-cerita pahlawan di sekeliling kehidupan untuk mengajar anak-anak tentang nilai keberanian, kehormatan, dan integritas.

Kedua, Weber dan Ruch (2011) melakukan penelitian mengenai peran karakter positif di sekolah. Penelitian ini menyelidiki peran karakter positif yang dihubungkan dengan kepuasan pengalaman anak di sekolah, keberhasilan tingkat akademik diri, perilaku positif di kelas, dan keberhasilan objektif sekolah. Secara lebih lanjut dijelaskan bahwa karakter yang berasal dan kekuatan pikiran (misalnya pengaturan diri, ketekunan, cinta belajar) bisa memprediksi keberhasilan anak di sekolah.

Ketiga, Martani (2012) menulis hasil penelitian mengenai peran cerita dalam menstimulasi perkembangan anak. Dalam penelitian ini ditemukan bahwa untuk menstimulasi perkembangan emosi anak usia dini, guru banyak menggunakan benda dan permainan yang berupa balok-balok, buku cerita, kaset/CD untuk bercerita dan mendengarkan lagu.

Keempat, Puspitoningrum melakukan penelitian untuk menghasilkan bahan ajar yang ideal berupa buku ajar yang berisi materi, latihan, evaluasi, dan refleksi yang dilengkapi multimedia interaktif serta bertujuan mendeskripsikan kelayakan berupa tingkat validitas, kepraktisan, kemenarikan, dan efektivitas produk bahan ajar.

Kelima, Islamy et.all. (2016) melakukan penelitian berkaitan dengan struktur cerita anak beserta kelayaknnya untuk dijadikan bahan ajar di SD dengan kategori layak, kurang layak, dan tidak layak untuk dijadikan bahan ajar.

\section{METODE PENELITIAN}

Penelitian ini menggunakan prosedur penelitian Research and Development (penelitian dan pengembangan) dari Borg dan Gall (1983:775-776). Kebutuhan penelitian ini disesuaikan dengan tujuan dan kondisi penelitian yang sebenarnya. Penelitian ini difokuskan pada langkah pertama dan kedua. Adapun hasil adaptasi langkah penelitian ini adalah: 1) kajian awal yang meliputi analisis kebutuhan yang meliputi (a) analisis struktur yang terdapat dalam cerita anak pilihan, (b) analisis keterkaitan antara tema dengan pengembangan jalan cerita pada cerita anak pilihan, dan (c) analisis kebutuhan psikologi perkembangan (kognitif, sosial, moral) dalam mengembangkan cerita anak; serta 2) pengembangan prinsip-prinsip pembuatan cerita anak berbasis psikologi perkembangan.

Variabel dalam penelitian ini meliputi variabel bebas dan terikat. Variabel bebas dalam penelitian ini adalah struktur dan jalan cerita yang terdapat dalam cerita anak. Adapun variabel terikat dalam penelitian ini adalah prinsip-prinsip pengembangan cerita anak berbasis psikologi perkembangan.

Dalam pengembangan prinsip-prinsip pengembangan cerita anak berbasis psikologi perkembangan, dibutuhkan tiga data yang berbeda, yakni (1) struktur cerita anak yang berkembang saat ini berupa deskripsi hasil analisis, (2) keterkaitan tema dan jalan cerita dalam cerita anak berupa deskripsi hasil analisis, dan (3) data analisis kebutuhan cerita anak berdasarkan psikologi perkembangan pada anak usia dini yang berupa skor kecenderungan pilihan jawaban.

Adapun dalam pengembangan prinsipprinsip cerita anak berbasis psikologi perkembangan, dibutuhkan tiga macam instrumen, yaitu (1) instrumen untuk mengetahui data hasil analisis struktur cerita anak, (2) instrumen untuk mengetahui data hasil analisis keterkaitan tema cerita dengan alur cerita, dan (3) instrumen untuk mengetahui analisis kebutuhan cerita anak berbasis psikologi perkembangan pada anak usia dini.

Data dalam penelitian ini diperoleh menggunakan analisis deskriptif kualitatif yaitu melalui pemaparan data dan verifikasi simpulan data. Teknik ini digunakan untuk mengetahui kebutuhan terhadap prinsip-prinsip pengembangan cerita anak berbasis psikologi perkembangan.

\section{HASIL DAN PEMBAHASAN}

Hasil penelitian dan pembahasan yang dipaparkan dalam penelitian ini meliputi 3 hal, yaitu (1) deskripsi hasil analisis struktur cerita anak yang berkembang saat ini, (2) deskripsi hasil analisis keterkaitan tema dan jalan cerita dalam cerita anak, dan (3) prinsip pengembangan sastra anak berbasis psikologi perkembangan berdasarkan hasil analisis kebutuhan pada anak usia dini.

\section{ANALISIS STRUKTUR CERITA ANAK MASA KINI}


Berdasarkan hasil analisis, diketahui bahwa seluruh cerita anak yang diwujudkan dalam dongeng anak nusantara dengan judul: 1) Legenda Danau Maninjau, 2) Lebai Nan Malang, 3) Hikayat Malin Deman, 4) Joko Kendil, 5) Nyi Anteh Sang Penunggu Bulan, 6) Cindelaras, 7) Keong Mas, 8) Ande-Ande Lumut, dan 9) Asal Mula Danau Batur tidak memiliki struktur yang lengkap. Struktur yang hilang dalam kumpulan dongeng tersebut adalah koda.

Cerita anak dikembangkan dengan beberapa struktur pokok, yaitu: orientasi, intrik, klimaks, antiklimaks, resolusi, dan koda. Orientasi merupakan bagian teks yang memberikan informasi mengenai apa, siapa, di mana, dan kapan yang ada di dalam cerita. Bagian ini biasanya terletak di awal paragraf. Intrik merupakan bagian cerita yang menggambarkan awal mulanya terjadi konflik, hal ini bisa juga dikaitkan dengan pemicu konflik menuju puncak. Klimaks adalah bagian cerita yang menceritakan puncak masalah yang dialami tokoh utama. Antiklimaks adalah bagian yang menggambarkan penurunan konflik menuju penyelesaian masalah. Pada bagian ini digambarkan masalah yang mulai menemukan celah tapi belum terselesaikan. Resolusi adalah tahap menyelesaikan masalah. Dan, koda merupakan komentar akhir terhadap keseluruhan isi cerita, dapat diisi dengan simpulan tentang hal-hal yang dialami tokoh utama serta nilai-nilai yang dapat diambil oleh pembaca. Dari keenam struktur tersebut, terdapat sebuah struktur yang kedudukannya menjadi wajib jika dihadapkan dengan anakanak sebagai pembacanya, yaitu koda. Koda biasanya terletak di akhir sebuah cerita yang berisi simpulan dan nilai yang dapat dipetik dari cerita yang telah dibaca.

Cerita yang berkembang di masyarakat merupakan cerminan suatu kehidupan. Berbagai peristiwa ditampilkan melalui rangkaian katakata untuk menggambarkan alur cerita. Cerita yang menarik ditampilkan dengan konflik yang menantang. Konflik ini dibangun melalui pertentangan peristiwa baik dan buruk untuk memancing emosi pembaca. Emosi pembaca inilah yang dijadikan sebagai tolok ukur kemenarikan sebuah cerita.

Serupa dengan konsep tersebut, cerita anak juga dibangun melalui berbagai peristiwa. Peristiwa ini dapat berupa peristiwa yang positif serta negatif. Melalui pertentangan kedua peristiwa inilah nilai kehidupan dapat dipetik. Sebagai pembaca pemula, anak-anak seringkali belum bisa menyimpulkan nilai yang dapat dipetik dalam cerita, hal ini menyebabkan terjadi kekacauan konsep nilai. Kekacauan konsep nilai ini akan berdampak pada pemberian kesimpulan yang salah yang tentu saja berpengaruh pada sikap dan pola pikir anak. Oleh karena itu, koda harus hadir dan diwujudkan melalui pesan tersurat agar mampu menjadi penggiring anak untuk memberikan simpulan yang positif dari sebuah cerita.

\section{ANALISIS KETERKAITAN TEMA DAN JALAN CERITA DALAM CERITA ANAK}

Berdasarkan hasil analisis dalam dongeng anak nusantara dengan judul: 1) Legenda Danau Maninjau, 2) Lebai Nan Malang, 3) Hikayat Malin Deman, 4) Joko Kendil, 5) Nyi Anteh Sang Penunggu Bulan, 6) Cindelaras, 7) Keong Mas, 8) Ande-Ande Lumut, dan 9) Asal Mula Danau Batur diketahui bahwa terdapat ketidaksamaan tema dengan rangkaian peristiwa yang dikembangkan. Rangkaian peristiwa yang dituliskan dalam dongeng anak nusantara tersebut banyak berisi hal-hal yang negatif, dan hal ini bertentangan dengan nilai yang akan diajarkan pada tema.

Tema merupakan gagasan utama dalam membuat cerita. Tema menjadi bagian penting di dalam sebuah cerita. Hal ini erat kaitannya dengan dasar yang dipakai oleh pengarang untuk mengembangkan sebuah cerita. Tema diwujudkan ke dalam sistematika alur untuk membangun sebuah cerita yang utuh.

Berkaitan dengan hal tersebut, tema dikembangkan menjadi runtutan peristiwa. Runtutan peristiwa inilah dasar pembangunan struktur cerita. Dengan dalih untuk menghidupkan cerita, terkadang pengarang menampilkan peristiwa-peristiwa yang bertentangan dengan nilai yang ada di masyarakat. Hal ini biasanya dijadikan sebagai puncak konflik. Selain untuk membuat suasana yang menegangkan, pemberian peristiwaperistiwa yang bertentangan ini juga dimaksudkan untuk membuat pembaca berpikir kritis mengenai respon atau timbal balik terhadap nilai yang akan diajarkan kepada pembacanya.

Jika dikaitkan dengan hal tersebut, pembaca membutuhkan proses menalar tingkat tinggi dengan membandingkan berbagai hal untuk kemudian memutuskan bahwa apa yang dibaca tersebut termasuk hal yang baik atau tidak baik. Sedangkan pada kenyataannya, cerita yang diwujudkan dalam dongeng tersebut banyak dibaca oleh pembaca anak-anak yang 
belum bisa menalar hingga sejauh itu. Baik anak-anak pada masa praoperasional (usia 2 s.d. 7 tahun) maupun masa operasional konkret (usia 7 s.d. 11 tahun) belum mampu berpikir logis dan mengambil kesimpulan lepas dari apa yang dialami (baik dilihat maupun dibaca) saat itu.

Pada masa praoperasional, anak dicirikan memiliki kemampuan menggunakan simbol yang mewakili suatu konsep. Jadi, ketika anak melihat suatu objek maka ia akan mulai mengenali objek tersebut. Misalnya, seorang anak yang pernah melihat dokter berpraktik, anak tersebut dapat bermain "dokter-dokteran". Adapun pada masa operasional konkret, anak memiliki ciri perkembangan sistem pemikiran yang didasarkan pada aturan-aturan tertentu yang logis. Tahap operasi konkret ini ditandai dengan adanya sistem operasi berdasarkan apaapa yang kelihatan nyata/konkret. Dalam hal ini, anak masih menerapkan logika berpikir pada hal yang konkret.

Jika dilihat dari ciri yang mendasari tersebut, dapat disimpulkan bahwa anak pada rentang usia dua tahun hingga sebelas tahun belum dapat menalar suatu hal dengan membandingkan konsep baik dan buruknya untuk kemudian membuat sebuah keputusan. Oleh karena itu, dalam memberikan sebuah pembelajaran pada usia tersebut haruslah diberikan langsung pada contoh yang nyata dan diutarakan nilai apa yang akan diajarkan. Akan tetapi, banyak ditemukan bentuk alur yang ditampilkan dalam cerita anak memiliki alur yang kompleks dengan memunculkan berbagai peristiwa baik dan buruk. Pembaca diharuskan membuat perbandingan dengan berbagai pertimbangan untuk menemukan nilai yang akan diajarkan. Hal ini ternyata bertentangan dengan tema yang diusung.

\section{PRINSIP PENGEMBANGAN CERITA ANAK BERBASIS PSIKOLOGI PERKEMBANGAN BERDASARKAN HASIL ANALISIS KEBUTUHAN PADA ANAK USIA DINI}

Prinsip pengembangan cerita anak berbasis psikologi perkembangan didasarkan pada dua pedoman, yaitu (1) hasil analisis kebutuhan cerita anak pada usia dini, serta (2) pedoman mengembangankan cerita anak berbasis psikologi perkembangan. Hasil sinkronisasi dari karakteristik data dari kedua pedoman tersebut kemudian dispesifikasikan menjadi prinsip-prinsip pengembangan. Prinsip tersebut selanjutnya dispesifikasi menjadi kaidah-kaidah teknis, sehingga dapat dijadikan acuan dalam mengembangkan cerita anak berdasarkan psikologi perkembangan pada anak usia dini.

\section{Analisis Kebutuhan Cerita Berdasarkan Psikologi Perkembangan pada Anak Usia Dini} Kebutuhan pengembangan cerita berdasarkan psikologi perkembangan pada anak usia dini mengacu pada hasil analisis kebutuhan menurut persepsi anak. Pada tahap ini dilakukan identifikasi kebutuhan pengembangan cerita menurut persepsi anak melalui angket sesuai dengan kecenderungan pilihan jawaban. Angket ini terdiri atas sembilan indikator, antara lain menanyakan tema, tokoh, penokohan, sudut pandang, latar, orientasi, alur, koda, serta susunan kalimat.

Berdasarkan hasil analisis diketahui bahwa (1) anak menyukai tema cerita yang mengajarkan nilai kejujuran, kepahlawanan, dan keberanian; (2) tokoh yang diharapkan adalah tokoh yang berwujud manusia; (3) penokohan yang diharapkan memiliki sifat yang baik; (4) pemilihan sudut pandang adalah sudut pandang orang ketiga; (5) latar tempat yang diharapkan adalah latar yang berada di lingkungan sekitar; (6) pada bagian orientasi, diharapkan ada perkenalan tokoh yang terlibat dalam cerita; (7) seluruh rangkaian alur dalam cerita digambarkan dengan peristiwa yang positif; (8) pesan disampaikan dalam bagian koda secara tersurat; dan (9) cerita disusun dengan kalimat tunggal.

\section{Pedoman Mengembangkan Cerita Anak Berbasis Psikologi Perkembangan}

Sastra anak-anak adalah sastra yang mencerminkan perasaan dan pengalaman anakanak melalui pandangan anak-anak (Norton 1993). Sebagai sebuah karya, sastra anak-anak menjanjikan sesuatu bagi pembacanya yaitu nilai yang terkandung di dalamnya yang dikemas secara intrinsik maupun ekstrinsik. Oleh karena itu, kedudukan sastra anak menjadi penting bagi perkembangan anak.

Resmini (2018) mengungkapkan bahwa sastra anak bermanfaat untuk perkembangan anak terutama dalam hal (1) perkembangan bahasa, (2) perkembangan kognitif, (3) perkembangan kepribadian, dan (4) perkembangan sosial. Sebuah karya dengan penggunaan bahasa yang efektif akan membuahkan pengalaman estetik bagi anak. Penggunaan bahasa yang imajinatif ini juga dapat menghasilkan responsi intelektual dan emosional sehingga anak akan merasakan dan menghayati peran tokoh dan konflik yang 
ditimbulkan. Selain itu, sastra anak akan turut membantu mereka menghayati keindahan, keajaiban, kelucuan, kesedihan dan ketidakadilan. Anak-anak akan merasakan bagaimana memikul penderitaan dan mengambil resiko, juga akan ditantang untuk memimpikan berbagai mimpi serta merenungkan dan mengemukakan berbagai masalah mengenai dirinya sendiri, orang lain dan dunia sekitarnya (Huck, 1987).

Berkait dengan hal tersebut, terdapat beberapa hal yang harus diperhatikan ketika proses pembuatan sastra anak tersebut, antara lain adalah sebagai berikut: (1) variasi tema, (2) faktor penentu responsi terhadap bacaan anak, (3) bahasa, (4) penuturan, (5) tokoh dan penokohan, serta (6) latar dan plot.

\section{Variasi tema}

Sastra anak dapat dikatakan sebagai dunia mini anak-anak. Anak-anak dapat belajar banyak hal dari cerita yang dibaca. Hal ini dikuatkan dengan pernyataan Resmini (2018) yang menyatakan bahwa sastra anak dapat dijadikan sebagi alat untuk memperoleh gambaran dan kekuatan dalam memandang dan merasakan serta menghadapi realitas kehidupan. Berkait dengan hal tersebut, pemilihan tema dapat diarahkan pada proses pemahaman dan pengenalan kehidupan yang nyata. Oleh karena itu, tema-tema tersebut dapat dibagi dalam beberapa jenis, yaitu tema keluarga, hidup dengan orang lain (berteman dan penerimaan oleh teman bermain), tumbuh dewasa, mengatasi masalah-masalah manusiawi dan hidup dalam masyarakat majemuk yang memuat perbedaan individu dan kelompok (Resmini 2018). Cerita yang memuat pengalaman mengenai realitas kehidupan ini disebut juga dengan cerita realistik.

\section{Faktor penentu responsi terhadap bacaan anak}

Dalam menanggapi sebuah bacaan sastra yang didengar atau dibacanya, masingmasing anak mempunyai cara tersendiri dalam mengungkapkan kesenangan, pikiran, dan perasaannya. Jika dikaitkan dengan teori kognitif yang dikemukakan oleh Piaget, terdapat perbedaan tahapan dalam perkembangan berpikir anak. Hal ini berkaitan dengan hasil interaksi dari lingkungan dan kematangan anak yang berbeda pula.

Jika dikaitkan antara perkembangan otak dan perkembangan kognitif anak, dapat dilihat bahwa perkembangan usia berhubungan dengan perkembangan kognitif yang dideskripsikan Piaget. Tahap pertama, periode sensorimotor merupakan periode awal perkembangan kognisi yang ditandai oleh bayi belajar untuk berjalan sekitar umur 2 tahun. Anak belajar selama periode ini melalui pengkoordinasian persepsi sensori dan kegiatan motorik. Mereka sedikit sekali memperhatikan kata-kata.

Tahap kedua, periode praoperasional ( 2 - 7 tahun), pada tahap ini anak belajar menyatakan dunianya secara simbolik melalui bahasa, permainan, dan gambar. Anak memiliki konsep berpikir egosentris yang didasarkan pada persepsi dan pengalaman langsung. Pada usia ini anak sudah mampu mengembangkan rangkaian cerita. Anak sudah mampu memahami struktur cerita berdasarkan hubungan tiga peristiwa dengan tanjakan laku (rising action). Anak sudah mampu mengantisipasi klimaks cerita. Karakteristik perkembangan kognitif anak praoperasional ini adalah kecenderungan meningkatkan perkembangan bahasa dan pembentukan konsep. Pada tahap ini anak sudah melakukan proses asimilasi, yakni anak mengasimilasi apa yang mereka dengar, lihat, dan rasakan dengan menerima konsep baru ke dalam skema yang telah dia miliki.

Tahap ketiga, periode operasi kongkret (7 - 11 tahun), pada tahap ini tanggapan anak terhadap sastra berubah. Karakteristiknya ditandai oleh pikiran yang fleksibel. Anak-anak sudah mampu melihat struktur sebuah buku, misalnya kisah dalam kisah, alur sorot balik, dan mampu mengidentifikasi berbagai sudut pandang cerita. Tahap terakhir terakhir adalah operasi formal (11 tahun ke atas), pada tahap ini anak sudah mampu berpikir abstrak, bernalar dari hipotesis ke simpulan logis. Mereka dapat menangkap rangkaian alur atau subalur dalam rangkaian pikirannya.

\section{Bahasa}

Ditinjau dari bahasa, bacaan cerita anak-anak sebaiknya memiliki ciri menggunakan bahasa yang sederhana. Dalam cerita anak, bahasa yang digunakan harus mempertimbangkan penggunaan kosakata dan kalimat. Agar makna bacaan cerita anak dapat dengan mudah dipahami oleh mereka, maka kata yang dipakai hendaknya sesuai dengan jenis kosakata yang semestinya dikuasai anak dengan mengacu pada kenyataan kongkret yang diasumsikan dekat dan akrab dengan kehidupan anak. Adapun dari segi kalimat, sebaiknya digunakan kalimat sederhana. Hal tersebut berarti tidak terlalu panjang dan tidak banyak 
menggunakan pelesapan kata. Dengan demikian, agar pengekspresian sesuatu lewat wahana bahasa yang terwujud dalam bentuk teks dan tersusun dalam bentuk sebuah cerita itu mudah dipahami anak, maka penggunaan bahasa sangatlah perlu diperhatikan kesesuaiannya terutama dengan tingkat kemampuan membaca anak.

\section{Penuturan}

Dari segi cara penuturan, ciri bacaan cerita anak diarahkan pada teknik penuturan cerita yang merujuk pada pemilihan kata, penggunaan gaya bahasa, teknik penggambaran tokoh dan latar cerita. Dalam teknik penuturan, pemilihan kata dan gaya bahasa hendaknya disesuaikan dengan readiness anak yaitu dengan menggunakan kata dan gaya bahasa yang kongkret sesuai dengan perkembangan kognitif mereka dan mengacu pada pengertian yang tersurat. Teknik penuturan latar dan tokoh sebaiknya lebih banyak digunakan teknik adegan dilengkapi dengan dialog atau penggambaran dan teknik montase yaitu penuturan berdasarkan kesan dan observasi yang tersaji secara asosiatif.

Teknik penuturan yang digunakan adalah teknik penyajian naratif yang banyak digunakan dalam cerita anak-anak. Meskipun demikian, di dalamnya didukung oleh reportasi dan deskripsi berupa ilustrasi gambar. Pemilihan teknik penuturan disesuaikan dengan keterbacaan anak seperti cara naratif atau bisa juga dengan menggunakan gaya penuturan lakuan melalui dialog dan narasi dan digambarkan secara hidup dan menarik sehingga terpahami oleh anak. Sedangkan penuturan secara langsung kurang cocok digunakan karena tidak mengembangkan imajinasi anak.

\section{Tokoh dan penokohan}

Dari segi tokoh, bacaan cerita anakanak menampilkan tokoh yang jumlahnya tidak terlalu banyak (tidak melebihi 6 pelaku). Ini dimaksudkan agar tidak membingungkan anak dalam memahami alur cerita yang tergambarkan lewat rentetan peristiwa yang ada. Penokohan atau karakterisasi tokoh dilakukan dengan tegas dan langsung menggambarkan wataknya dengan dilengkapi oleh penggambaran fisik dengan cara yang jelas. Karakterisasi juga bisa dilakukan melalui penggambaran perilaku tokoh-tokoh yang tergambarkan dalam alur. Motivasi dan peran yang diemban para tokoh digambarkan dengan tegas secara imajinatif.

\section{Latar dan plot}

Latar cerita anak hendaknya disesuaikan kedekatannya dengan kehidupan anak misalnya, lingkungan rumah, sekolah, tempat bermain, kebun binatang, dan lain-lain. Latar cerita yang digunakan harus mampu mengaktualisasikan dan menghidupkan cerita. Dari segi alur atau plot, bacaan cerita anak-anak mengandung plot yang bersifat linier dan berpusat pada satu cerita sehingga tidak membingungkan anak. Rentetan peristiwanya dikisahkan dengan cara yang tidak kompleks dan menunjukkan hubungan sebab akibat yang diungkap secara jelas dan digambarkan secara hidup dan menarik.

Point of view dalam cerita anak-anak dipilih penutur dan disesuaikan dengan karakteristik gambaran peristiwanya. Penutur tidak meng-aku-kan diri yang berperan sebagai pelaku karena akan menimbulkan kesan aneh. Jadi hendaknya penuturan langsung menggunakan penyebutan nama.

\section{Prinsip Mengembangkan Cerita Anak Berbasis Psikologi Perkembangan}

Prinsip mengembangkan cerita anak berbasis psikologi perkembangan berdasarkan hasil sinkronisasi karakteristik data dari hasil analisis kebutuhan cerita anak pada usia dini serta pedoman mengembangankan cerita anak berbasis psikologi perkembangan. Prinsip tersebut selanjutnya dispesifikasi menjadi kaidah-kaidah teknis, sehingga dapat dijadikan acuan dalam mengembangankan cerita anak berbasis psikologi perkembangan. Adapun prinsip-prinsip tersebut meliputi struktur, unsur intriksik, dan unsur ekstrinsik. Hal tersebut dapat diuraikan sebagai berikut.

\section{Struktur}

Bagian ini berisi prinsip pengembangan struktur dalam menulis cerita anak. Struktur yang wajib hadir dalam cerita anak adalah orientasi, komplikasi, resolusi, dan koda. Gambaran mengenai prinsip pengorganisasian struktur dapat dilihat pada tabel berikut.

\begin{tabular}{|c|l|l|}
\hline Subaspek & \multicolumn{1}{|c|}{ Prinsip } & \multicolumn{1}{|c|}{ Kaidah } \\
\hline $1 . \quad$ Struktur & Orientasi & $\begin{array}{l}\text { Berisi } \\
\text { pengenalan } \\
\text { tokoh yang akan } \\
\text { diceritakan } \\
\text { dalam cerita. }\end{array}$ \\
\cline { 2 - 3 } & Komplikasi & $\begin{array}{l}\text { Konflik dalam } \\
\text { cerita dibentuk } \\
\text { dari } \\
\text { permasalahan }\end{array}$ \\
\hline
\end{tabular}




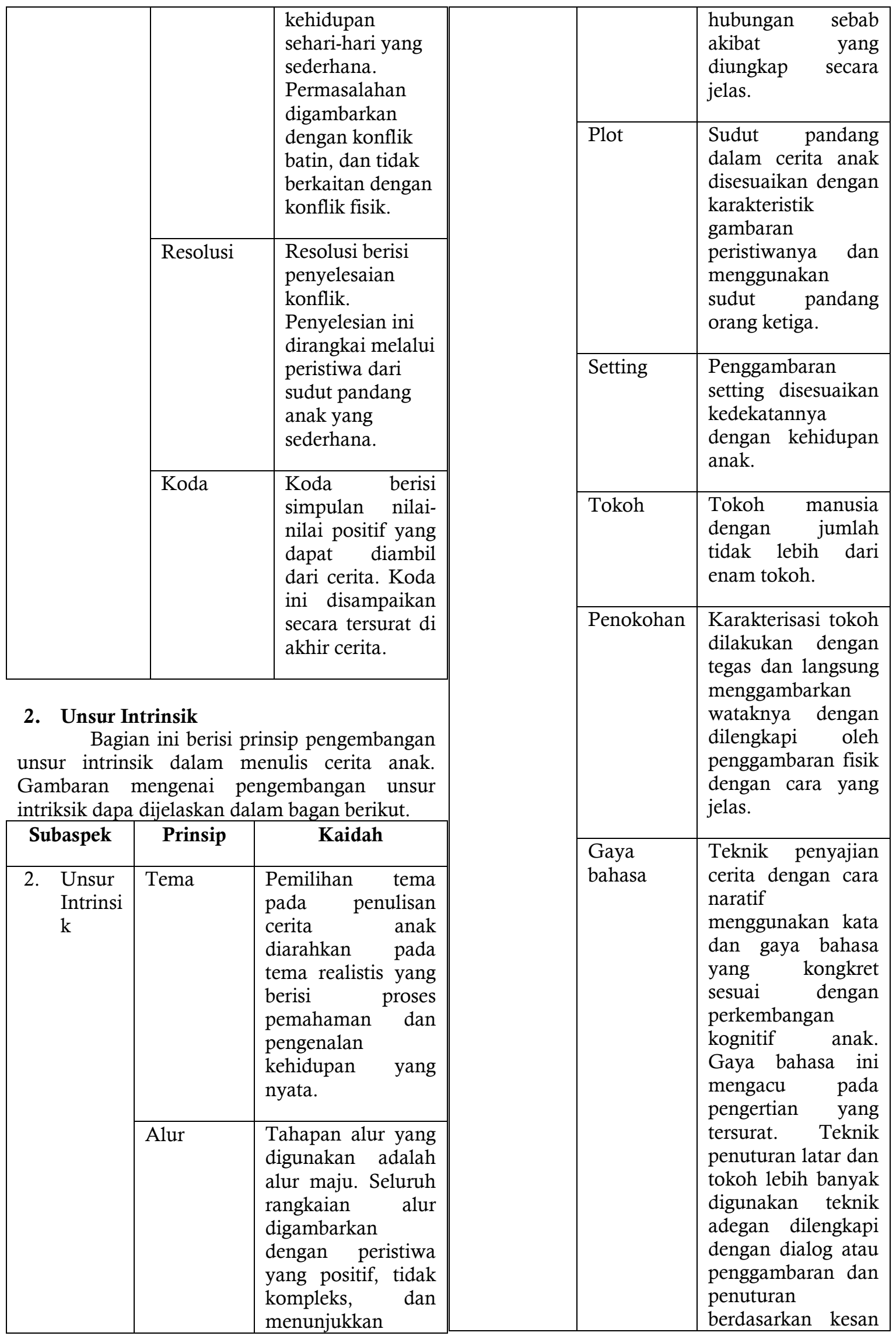




\begin{tabular}{|l|l|l|}
\hline & $\begin{array}{l}\text { dan observasi yang } \\
\text { tersaji secara } \\
\text { asosiatif. }\end{array}$ \\
\hline
\end{tabular}

\section{Unsur Ekstrinsik}

Bagian ini berisi prinsip pengembangan unsur ekstrinsik dalam menulis cerita anak. Gambaran mengenai pengembangan unsur ekstrinsik dapat dijelaskan dalam bagan berikut.

\begin{tabular}{|l|l|l|}
\hline Subaspek & Prinsip & \multicolumn{1}{|c|}{ Kaidah } \\
\hline $\begin{array}{l}\text { 3. } \\
\text { Ekstrin } \\
\text { sik }\end{array}$ & Nilai-nilai & $\begin{array}{l}\text { Nilai-nilai yang } \\
\text { dimasukkan dalam } \\
\text { cerita merupakan } \\
\text { nilai konkret yang } \\
\text { bersumber r dari } \\
\text { kehidupan anak } \\
\text { sehari-hari. }\end{array}$ \\
& & $\begin{array}{l}\text { Menghubungkan } \\
\text { pengalaman } \\
\text { pengarang yang } \\
\text { memililiki nilai } \\
\text { positif dengan dunia } \\
\text { anak. }\end{array}$ \\
\cline { 2 - 3 } & $\begin{array}{l}\text { Latar } \\
\text { belakang } \\
\text { pengarang }\end{array}$ \\
\hline
\end{tabular}

Dongeng sebagai salah satu sarana menanamkan pendidikan karakter diharapkan dapat menjadi perantara untuk meningkatkan kompetensi anak terutama dalam menghadapi tantangan di abad 21. Berkaitan dengan hal tersebut, Wagner (2010) mengidentifikasi kompetensi dan keterampilan yang diperlukan oleh anak dalam menghadapi kehidupan, dunia kerja, dan kewarganegaraan di abad ke-21 ditekankan pada tujuh keterampilan berikut: (1) kemampuan berpikir kritis dan pemecahan masalah, (2) kolaborasi dan kepemimpinan, (3) ketangkasan dan kemampuan beradaptasi, (4) inisiatif dan berjiwa entrepeneur, (5) mampu berkomunikasi efektif baik secara oral maupun tertulis, (6) mampu mengakses dan menganalisis informasi, dan (7) memiliki rasa ingin tahu dan imajinasi. Oleh karena itu, dongeng harus dibangun dan dibuat dengan prinsip yang sesuai, yaitu berdasarkan dengan psikologi perkembangan anak. Ketiga prinsip tersebut dijadikan dasar untuk mengembangkan sebuah dongeng yang telah mempertimbangkan psikologi perkembangan anak. Harapannya, dengan mendasarkan pada prinsip tersebut anak mampu memahami isi dongeng dengan baik sehingga dapat meningkatkan kempetensinya.
Berdasarkan hasil dan pembahasan, dapat disimpulkan bahwa seluruh cerita anak yang diwujudkan dalam dongeng anak nusantara tidak memiliki struktur yang lengkap, yaitu koda. Selain itu, diketahui pula terdapat ketidaksamaan tema dengan rangkaian peristiwa yang dikembangkan. Rangkaian peristiwa yang dituliskan dalam dongeng anak nusantara banyak berisi hal-hal yang negatif, dan hal ini bertentangan dengan nilai yang akan diajarkan pada tema.

Berdasarkan hasil sinkronisasi karakteristik data dari hasil analisis kebutuhan cerita anak pada usia dini serta pedoman mengembangankan cerita anak berbasis psikologi perkembangan, didapatkan tiga prinsip dasar pengembangan cerita anak, yaitu 1) struktur yang meliputi orientasi, komplikasi, resolusi, dan koda; 2) unsur intrinsik yang meliputi tema, amanat, latar, plot, tokoh, penokohan, dan gaya bahasa; serta 3) unsur ekstrinsik yang meliputi nilai-nilai dan latar belakang pengarang.

\section{DAFTAR PUSTAKA}

Gall, Meredith D., Joyce P. Gall, dan Walter R. Borg. 1983. Educational Research: An Introduction (4th ed.). New York: Pearson Education,Inc.

Islamy, et.all. 2016. "Cerita Anak Karya Mahasiswa PGSD UPI Kampus Tasikmalaya Berdasarkan Kriteria Pemilihan Bahan Ajar di SD". Jurnal Universitas Pendidikan Indonesia.

Jabrohim, Suminto A. Sayuti, dan Chaerul Anwar. 2003. Cara Menulis Kreatif Yogyakarta. Pustaka Pelajar.

Puspitoningrum, Encil. 2015. "Pengembangan Bahan Ajar Mendengarkan Cerita Anak untuk Sekolah Dasar Kelas Tinggi". Jurnal Universitas Nusantara PGRI Kediri.

Resmini, Novi. 2018. Sastra Anak dan Pengajarannya di Sekolah Dasar. Universitas Pendidikan Indonesia.

Sarumpaet, Riris K. Toha. 2012. "Struktur Bacaan Anak" dalamKreatif Menulis Cerita Anak. Bandung: Nuansa.

\section{SIMPULAN}


Sarumpaet, Riris K. Toha. 2010. Pedoman Penelitian Sastra Anak. Jakarta: Buku Obor.

Titik, W.S. 2003. Teknik Menulis Cerita Anak. Yogyakarta: Pinkbooks.

Titik, W.S. 2012. "Menulis Fiksi Cerita Pendek" dalamKreatif MenulisCerita Anak. Bandung: Nuansa.

Tucker, M. Catherine. 2006. "The Journey from Telling to Being: NarrativeWays of Understanding Applied to South African Children's HeroStories". International Journal for the Advancement of Counselling, Vol. 28, No. 3, September 2006.

Wagner, T. 2010. Overcoming The Global Achievement Gap (online). Cambridge, Mass., Harvard University.

Weber, Marco dan Willibald Ruch. 2011. "The Role of a Good Character in12-YearOld School Children: Do Character Strengths Matter inthe Classroom?" Springer Science Business Media B.V. 2011Published online: 19 November 2011. 